P-ISSN: 2774-4574; E-ISSN: 2774-4582

TRILOGI, 2(3), September-Desember 2021 (324-331) @2021 Lembaga Penerbitan, Penelitian, dan Pengabdian kepada Masyarakat (LP3M) Universitas Nurul Jadid Paiton Probolinggo

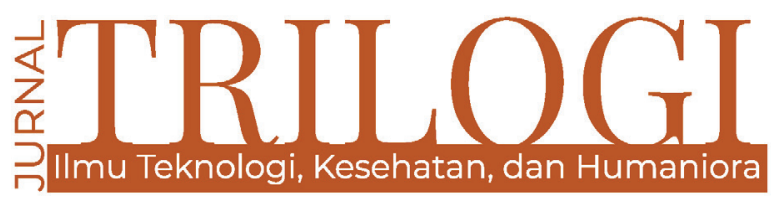

\title{
SENJAKALA MEDIA CETAK: TANTANGAN JURNALISME CETAK DI ERA DIGITAL
}

\author{
Abu Khaer \\ Universitas Nurul Jadid, Probolinggo, Indonesia \\ rikoufeliza@gmail.com \\ Nadiatul Khoir \\ Universitas Nurul Jadid, Probolinggo, Indonesia \\ Yulis Arini Hidayati \\ Universitas Nurul Jadid, Probolinggo, Indonesia
}

\begin{abstract}
Abstrak
Penelitian ini bertujuan untuk menganalisis tantangan media cetakjurnalistik di era digital. Perkembangan media onlinekini menjadi ancaman bagi surat kabar dan media cetak. Perkembangan internet yang pesat telah mendorong masyarakat untuk mengakses media online dengan mudah melalui handphone, atau gadget. Media cetak terancam terancam, dan pembaca setia media cetak cenderung beralih ke media online. Hasilmenunjukkan bahwa tantangan terbesar jurnalis di dunia digital. Era informasi identik dengan persaingan antarmedia mainstream dan media baru dalam hal ini media online. Pihak yang merasakan dampak signifikan dengan hadirnya online media adalah jurnalistik yang tentu saja sudah memiliki yang barusaluran untuk menyebarkan informasi dan berita.
\end{abstract}

Kata kunci: jurnalistik; media cetak; zaman digital

\begin{abstract}
This study aims to analyze the challenges of journalistic print media in the digital era. The development of online media is now a threat to newspapers and print media. The rapid development of the internet has encouraged people to easily access online media via mobile phones, or gadgets. Print media is under threat, and loyal readers of print media tend to turn to online media. The results show that the biggest challenge for journalists in the digital world. The information age is synonymous with competition between mainstream media and new media, in this case online media. Those who feel a significant impact with the presence of online media are journalists who of course already have new channels for disseminating information and news.
\end{abstract}

Keywords: journalism; print media; digital age 


\section{Pendahuluan}

Era digital bisa dikatakan berpengaruh di segala bidang kehidupan manusia, tak terkecuali jurnalistik. Pesatnya perkembangan internet mendorong masyarakat untuk mengakses secara onlinemedia dengan mudah melalui handphone, atau gadget. Media cetak terancam bahayaterancam, dan pembaca setia media cetak kemungkinan besar akan beralih ke media online. Realitamengancam penerbit media cetak, namun media cetak memiliki ciri khas yaitu: jelas,berita lengkap dan detail, selain itu selama berabadabad media cetak telah mengiringiperkembangan peradaban manusia, sehingga tidak mudah dilupakan. Media online cepat, up-to-tanggal dan berkelanjutan, tetapi berita ini hanya dapat diakses menggunakan alat canggih dan tidak semuaorang memiliki alat dan memahami teknologinya.

Media cetak, meskipun dari segi jumlah, mengalami peningkatan yang cukup signifikan dari segipembaca. Data Badan Pusat Statistik menunjukkan bahwa penduduk berusia 10 tahun ke atasyang membaca koran sebesar 23,0\%. Pada tahun 2006 mengalami penurunan sebesar 0,3\%. Penurunan drastisterjadi pada tahun 2009 dimana pembaca surat kabar menurun menjadi 18,4\% dan pada tahun 2012 turun lagi sebesar $17 \%$.Artinya dalam konteks pembaca dan pasar, liputan media cetak menurun dantentunya pada akhirnya akan menyebabkan industri pers tutup. Fenomena darimedia online yang diprediksi akan menggantikan media cetak juga terus meningkatIndonesia. Data Badan Pusat Statistik menunjukkan bahwa pada tahun 2005 pengguna internet diIndonesia baru mencapai 3,34 persen. Jumlah pengguna internet mengalami peningkatan yang signifikanmeningkat menjadi $35,64 \%$ pada tahun 2014. Artinya dalam kurun waktu sembilan tahun terjadi sepuluh kali lipatmeningkat. Tentu saja ini memberikan kontribusi bagi masa depan media cetak.

Internet membuka ruang publik bagi partisipasi warga, baik profesional maupunamatir dalam penyebaran informasi. Informasi tidak lagi eksklusif untuk jurnalis danmedia. Pekerjaan jurnalistik kini juga dilakukan oleh publik. Ini adalah era yang disebut AlvinToffler, futurolog 1980-an sebagai era konsumsi (produksi dan konsumsi). Itumasyarakat dapat menjadi produsen dan konsumen informasi. Stephen JA Ward, profesor dari etika jurnalistik di University of Wisconsin Madison, dalam artikelnya Digital
Media Ethics,mencatat bahwa kehadiran internet membuat jurnalis profesional saat ini berbagi ruang denganTwitter, blogger, jurnalis warga, dan pengguna media sosial. Catatan sejarah, media baru adalahselalu hadir seiring dengan perkembangan teknologi. Internet membuat manusia sepertihidup di desa global (global village). Internet sebagai media juga telah mempengaruhicara kita hidup, termasuk cara kita memproduksi dan mengonsumsi berita.

Dalam bukunya tahun 2006 The Vanishing Newspaper, Philip Meyer meramalkan bahwa pada tahun 2044 adahanya akan menjadi satu salinan surat kabar. Masa depan surat kabar telah menjadi pertanyaan besar didi tengah gempuran TV, radio bahkan internet. Sejumlah survei menunjukkanbahwa posisi surat kabar sedang tergerus oleh penetrasi media online.

Ada beberapa aspek media massa yang menjadikan dirinya penting sehinggamenampilkan karya dan gagasan melalui media massa merupakan hal yang strategis. Pertama, jangkauan yang sangat luasdalam menyebarluaskan informasi yang mampu lintas batas (geografis), kelompok umur, jenis kelamin,status sosial, kebebasan (demografis) dan perbedaan pemahaman dan orientasi(psikografis). Kedua, kemampuan media untuk melipatgandakan pesan yang luar biasa. Ketiga,setiap media massa dapat mendiskusikan suatu ide atau karya sesuai dengan pandangannya masing-masing. Keempat,Dengan fungsi agenda setting, media massa memiliki banyak kesempatan untuk berbagi ideatau bekerja.

Kebebasan dan tanggung jawab isi pesan sebagai etika komunikasi adalahterkadang masih kontradiktif dalam pelaksanaannya. Dalam filsafat, pengertian kebebasan adalah kemampuan manusia untuk menentukan dirinya sendiri. Kebebasan lebih positif dan ada sebagai konsekuensi dari potensi manusia untuk dapat berpikir dan berkehendak. Sudah menjadi sifat manusia untuk menjadi makhluk yang memiliki kebebasan, bebas berpikir, berkehendak, dan berbuat. Pengertian tanggung jawab adalah kemampuan manusia yang menyadari bahwa segala perbuatannya selalu ada konsekuensinya.

\section{Tinjauan Pustaka}

\section{Konsep Jurnalistik}

Jurnalisme dalam pengertiannya, berasal dari kata " jour " (Perancis) yang berarti "buku harian". Sejak zaman Romawi kuno, Julius Caesar sudah 
mengenal kata " Acta Diurma ". Yang berartisemua kegiatan dari hari ke hari (pengumuman pemerintah, dII). Istilah jurnalisme di siniwaktu, mungkin sudah tidak asing lagi di telinga. Di era sekarang ini, berbagai informasi danmedia telekomunikasi sangat mempengaruhi sikap dan perilaku masyarakat, terutama dalamperkotaan, bahkan media massa dapat mempengaruhi masyarakat hingga ke pelosok pedesaan. Dalam hal nyaAsal usul istilah jurnalistik berasal dari kata jurnalistik (Belanda), mirip dengan istilah dalam bahasa Inggrisyaitu Jurnalisme yang berasal dari kata journal yang merupakan terjemahan daribahasa latin diurna yang berarti "setiap hari" atau "setiap hari", dimana semua berita pada hari ituterkandung dalam lembaran-lembaran kertas yang dicetak.

Dalam Kamus Besar Bahasa Indonesia disebutkan bahwa jurnalistik adalah karya menghimpun,menulis, mengedit, dan menerbitkan berita di surat kabar dan sebagainya, yang melibatkan jurnalisme danpesan. Jurnalistik menurut Onong U. Effendi, jurnalistik adalah mengelola berita dari mendapatkan bahan untuk disebarluaskan kepada masyarakat. Awalnya jurnalisme hanya mengatur hal-halyang informatif. Hal itu dibuktikan dengan Acta Diurma sebagai produk jurnalis pertama dizaman Romawi kuno, ketika kaisar Julius Caesar berkuasa.

Pengertian jurnalisme dapat ditinjau dari tiga sudut pandang: 1)Harfiyah, 2) Konseptual/ Teoretis, 3) Praktis. Secara harfiyah, jurnalistik berarti jurnalistikatau kepengarangan. Kata dasar "journal", berarti laporan atau catatan, atau " jour " dalam bahasa Prancis yang berarti "hari". Asal usul kata jurnalistik dari bahasa Yunani Kuno, " du jour " yang artinyahari, yaitu peristiwa hari ini yang dilaporkan dalam lembaran tercetak. Secara konseptual, jurnalisme dapatdipahami dari tiga sudut pandang: a) Prosa, b) Teknik, c) Sains. Sebagai sebuah proses,jurnalisme adalah "kegiatan" mencari, mengolah, menulis, dan menyebarkan informasikepada masyarakat melalui media massa. Kegiatan ini dilakukan oleh wartawan. SebagaiTeknik jurnalistik adalah "keahlian" atau "keterampilan" menulis karya jurnalistik (berita, artikel, danfitur) termasuk keahlian dalam mengumpulkan bahan tulisan seperti melaporkan peristiwa danwawancara.

\section{Berita}

Berita adalah laporan peristiwa yang memiliki nilai jurnalistik atau memiliki nilai berita - aktual, faktual,penting, dan menarik. Berita disebut juga "informasi terbaru". Jenis berita antara lain: a) Berita langsung (Straight News / Spot News / Hard News), b) Berita opini, c) Investigatifberita, d) Soft News. Views adalah pandangan atau opini tentang suatu isu atau peristiwa. Jenis iniinformasi termasuk kolom, editorial, artikel, surat pembaca, karikatur, sudut, danesai. Ada juga tulisan yang tidak memuat berita juga tidak bisa disebut opini,yaitu features yang merupakan gabungan antara news dan views. Jenis yang paling populerfitur adalah fitur tips (cara melakukannya fitur), fitur biografi, catatan perjalanan / petualangan, dan fitur minat manusia.

Secara khusus, bahasa jurnalistik dapat dibedakan menurut bentuknya, yaitu bahasa jurnalistik surat kabar, bahasa jurnalistik tabloid, bahasa jurnalisme majalah, bahasa jurnalisme radio siaran, bahasajurnalisme televisi, dan bahasa jurnalisme media online internet. bahasa darijurnalisme surat kabar, kecuali tunduk pada aturan umum atau prinsip jurnalistik bahasa, juga memiliki ciri-ciri yang sangat spesifik atau khusus. Ini yang membedakannyadari bahasa jurnalistik media lainnya. Ada tujuh belas ciri utama jurnalistik bahasa yang berlaku untuk semua bentuk media periodik, yaitu: Sederhana, Singkat, Padat, Sederhana,Jelas, Menarik, Demokratis, Populis, Logis, Tata Bahasa, Menghindari ucapan, Menghindarikata dan istilah asing, Pilihan kata (diksi) yang tepat, Mengutamakan kalimat aktif,Menghindari kata-kata atau istilah teknis, Tunduk pada prinsip-prinsip etika.

Media Cetak sebagai Media MassaMedia cetak adalah media tertua yang ada di muka bumi. Media cetak berasal dariMedia yang disebut Acta Diuna dan Acta Senatus di Kekaisaran Romawi, kemudian berkembang pesat setelah Johanes Guttenberg menemukan mesin cetak sampai sekarang memiliki berbagai macam bentuk, seperti:surat kabar, tabloid, dan majalah. Media cetak adalah semua barang cetakan yang digunakan sebagai sarana penyampaian pesan seperti yang telah disebutkan sebelumnya, berbagai media cetak pada umumnya.

Selain itu menurut Suharyanto (2018) pesan yang harus disampaikan harus berbayar, dalam iklan juga terjadi proses identifikasi sponsor. Iklantidak hanya menampilkan pesan tentang kehebatan produk yang ditawarkan, tetapi juga menyampaikan pesan agar konsumen mengetahui perusahaan yang memproduksi produk yang ditawarkan.

Sejarah media modern dimulai dengan buku cetak. Meskipun awalnya bukuupaya pencetakan 
hanya upaya menggunakan alat-alat teknis untuk menghasilkan yang sama atau hampirteks yang sama, yang telah disalin dalam jumlah besar, tetapi upaya itu tentu saja masih bisadisebut semacam revolusi. Lambat laun perkembangan buku cetak mengalami perubahandari segi konten semakin sekuler dan praktis. Kemudian semakin banyak karya populer,terutama dalam bentuk brosur dan pamflet politik dan agama yang ditulis dalam bahasa daerah bahasa, memainkan peran dalam proses transformasi abad pertengahan. Jadi, pada saatRevolusi dalam komunitas buku juga memainkan peran yang tidak dapat dipisahkan dariproses revolusi itu sendiri.

Hampir dua ratus tahun setelah penemuan mesin cetak, apa yang kitasekarang dikenal sebagai surat kabar prototipe dapat dibedakan dari surat edaran, pamflet, danbuku berita akhir abad keenam belas dan ketujuh belas. Pada kenyataannya jelas bahwa itu adalahsurat yang merupakan bentuk awal surat kabar, bukan lembaran berbentuk buku. Bundarberedar melalui layanan pos yang belum sempurna dan perannya terutama untukmenyebarluaskan berita mengenai peristiwa yang berkaitan dengan perdagangan internasional. Jadi, munculnyasurat kabar merupakan perkembangan dari aktivitas yang sudah berlangsung lama dalam dunia diplomasi danlingkungan bisnis. Surat kabar awal ditandai oleh: bentuk permanen; komersialalam (dijual bebas); bertujuan banyak (memberi informasi, mencatat, menyajikan hipertensi,hiburan, dan rumor); publik dan terbuka.

Dalam pengertian pengertian di atas, media cetak (surat kabar dan majalah) memilikitingkat inovasi yang lebih tinggi daripada buku cetak penemuan bentuk-bentuk baru tulisan, sosial danbudaya - meskipun pada saat itu pandangan yang muncul tidak demikian. Keistimewaan darisurat kabar, jika dibandingkan dengan sarana komunikasi budaya lainnya, terletak pada individualisme,orientasi pada realitas, kegunaan, sekularitas (nilai), dan kesesuaiannya dengan tuntutankebutuhan kelas sosial baru, yaitu kebutuhan pengusaha perkotaan danprofesional. Kualitas kebaruan tidak terletak pada elemen teknologi atau caradistribusinya, tetapi dalam fungsinya yang sesuai untuk kelas sosial tertentu dalam suatu perubahaniklim kehidupan dan suasana yang lebih permisif (terbuka) secara sosial dan politik.Sejarah perkembangan surat kabar dan majalah kemudian dapat digambarkan sebagaiserangkaian perjuangan, kemajuan dan pengulangan, yang mengarah pada iklim kebebasan, atau bisa jugadilihat sebagai kelanjutan dari sejarah kemajuan ekonomi dan teknologi. Pentingunsur-unsur dalam sejarah pers yang mempengaruhi batas-batas surat kabar dan majalah modern akandisajikan dalam paragraf berikut. Memang sejarah perkembangan persdari masing-masing bangsa tidak mungkin dijelaskan dalam satu presentasi singkat. Selain itu, ituPerlu dicatat bahwa elemen-elemen penting ini, yang sering berbaur dan berinteraksi satu sama lainlainnya, merupakan faktor penentu dalam perkembangan lembaga pers. Tentu saja, dengantingkat pengaruh yang berbeda.

Setiap media memiliki kelebihannya masingmasing, media cetak juga memiliki kelebihan dibandingkan denganmedia elektronik. Keunggulan media cetak pada umumnya dibandingkan dengan media elektronik terletakdalam "daya tahan" informasi. Dari berbagai jenis media massa, media cetak memilikikeunggulan yang tidak dimiliki oleh media lain. Hasil cetakannya permanen dan bisa disimpan begituagar pembaca dapat mengulanginya sampai memahami isi pesan yang disampaikan,tanpa biaya tambahan. Selain itu, halaman media cetak, menurut Mondry, dapat terus menjadiditambahkan jika diperlukan.

Menurut Wahyudin kelebihan media cetak adalah sebagai berikut: 1) Dapat dibacaberkalikali dengan menyimpannya. 2) Dapat membuat orang berpikir lebih spesifik tentang isitulisan. 3) Dapat disimpan atau dikumpulkan isi informasinya. 4) Harganya lebih mahalterjangkau dan dalam pendistribusiannya. 5) Lebih mampu menjelaskan hal-hal yang kompleks atau kaku. Ada dua jenis media cetak yang berkembang di tengah masyarakat, yaitu: koran dan majalah. Kedua media cetak ini memiliki keunggulan, yaitu:Kelebihan surat kabar adalah: 1) Biasanya relatif murah. 2) Fleksibel (lebihfleksibel dalam menentukan jadwal publikasi iklan dan surat kabar yangmempublikasikan (baik lokal, regional atau nasional) terkait dengan audiens yang ditargetkan oleh iklan). 3) Bisa dinikmati lebih lama. 4) Cakupan pasar; surat kabar mampu menjangkau daerah perkotaanmenurut daerah mereka. 5) Perbandingan belanja; surat kabar sering digunakan sebagai referensi atauacuan bagi konsumen dalam membeli barang atau jasa. 6) sikap konsumen yang positif; ituaktualitas informasi yang disampaikan juga dijadikan acuan bagi pembaca.

Sedangkan kelebihan majalah adalah sebagai berikut: 1) Dapat dinikmati lebih lama (long life .).span) Pembacaan lebih selektif. 2) Dapat 
mengekspresikan gambar yang menarik (Visual Quality). 3)Target audiens; salah satu keunggulan majalah jika dibandingkan dengan media lain adalahkemampuan untuk menjangkau segmen pasar khusus tertentu. 4) Penerimaan publik; kemampuan mengangkatproduk yang diiklankan sesuai dengan persepsi khalayak sasaran terhadap majalahprestise.

Kekurangan Media Cetak adalah : 1) Dari segi waktu media cetak lambat dalammenyediakan informasi. Karena media cetak tidak bisa menyebarkan berita secara langsung kepada masyarakatdan harus menunggu untuk dicetak. 2) Media cetak hanya dapat berupa tulisan. 3) Hanya media cetakdapat memberikan visual berupa gambar yang mewakili seluruh isi berita. 4)Biaya produksi cukup mahal karena media cetak harus mencetak dan mengirimkannya terlebih dahuludapat dinikmati oleh masyarakat.

Kemudian kekurangan surat kabar adalah: 1) Mudah diabaikan \& cepat basi. 2) Pendekmasa hidup; meskipun jangkauannya luas dan massal serta dapat didokumentasikan, pembaca surat kabarhanya membutuhkan waktu sekitar 15 menit hingga 30 menit untuk membacanya dan umumnya hanya membacanya sekali. 3) Kekacauan; Jika isi dan tata letak kacau akan mempengaruhi makna dan pemahamanisi pesan iklan oleh pembaca. 4) Terbatasnya cakupan kelompok tertentu; golongan tertentu tidak dapat dijangkau oleh surat kabar, misalnya kalangan menengah ke bawahmasyarakat atau orang yang berusia di bawah 15 tahun. 5) Produk yang tidak sesuai; beberapa produk tidak bisadiiklankan menggunakan surat kabar karena memerlukan demonstrasi atau memerlukanpertimbangan. Contoh iklan alat olahraga. 6) Jenis bahan yang digunakan adalahbiasanya mudah sobek, artinya gangguan mekanis tinggi, sehingga informasi yang diterimatidak lengkap.

Juga kekurangan Majalah adalah : 1) Biaya yang relatif mahal. 2) Fleksibilitas rendah (terbatas). 3) Distribusi. Banyak majalah beredar sangat lambat sehingga hanya menumpukrak toko. Ada juga majalah yang tidak memiliki jaringan distribusi yang tepat. 4) Dalamdaerah tertentu dengan daya beli tinggi tetapi sulit dijangkau, majalah sering tidak ada. 5)Jenis material yang digunakan biasanya mudah sobek, artinya gangguan mekanis yang tinggi,sehingga informasi yang diterima tidak lengkap.

\section{Hasil dan Pembahasan}

Islam sebenarnya lahir dengan konsepsi hubungan manusia yang berdasarkan keadilan atauPerkembangan media online kini telah menjadi ancaman bagi surat kabar dan media cetak. ItuPerkembangan internet yang pesat mendorong masyarakat untuk mengakses media online dengan mudahmelalui handphone, atau gadget. Media cetak terancam terancam, dan loyalpembaca media cetak cenderung beralih ke media online. Kenyataan ini memang mengancampenerbit media cetak, namun media cetak memiliki ciri khas yaitu: jelas, lengkapdan berita rinci, selain itu selama berabad-abad, media cetak telah mengiringi perkembangannyaperadaban manusia, sehingga tidak mudah dilupakan. Media online cepat, up-to-date danterus menerus, tetapi berita ini hanya dapat diakses menggunakan alat yang canggih dan tidak semua orangmemiliki alat dan memahami teknologi. Namun demikian, media cetak telah mengantisipasiawal dengan membuat media online untuk mendampingi media cetak yang diterbitkan.

Tren penurunan media cetak dan penggantian ledakan media digital dapatterlihat pada hasil penelitian Galarneau dan Joseph yang menunjukkan bahwa konsumenpenerbit majalah berkumpul di American Magazine Publisher di 5th DigitalKonferensi di New York pada 3 Maret 2009. Bahwa tren media cetak sedang menurun danpeserta mendengar tentang ledakan media digital di industri majalah. Itudiskusi termasuk membahas bagaimana memanfaatkan situs web dengan lebih baik, menjembatani divisiantara editorial dan bisnis, tren produk baru, dan perencanaan strategis, pemasaran daniklan di Internet. Mulai menggeser kebiasaan konsumen mengkonsumsi media barumenggunakan koneksi internet dan mulai meninggalkan media tradisional merupakan ancaman bagikeberlanjutan media cetak. Padahal media online belum bisa diakses oleh semua kalangankarena masih ada beberapa daerah dengan koneksi internet terbatas, media cetak masih mengantisipasi kehadiran media online dengan melakukan berbagai upaya, salah satunya media konvergensi.

Resmadi dan Yuliar mengungkapkan bahwa konvergensi media merupakan salah satu media massaperkembangan yang melibatkan banyak faktor teknologi di dalamnya. Kehadiran internet telahmendorong media massa untuk menerapkan konsep konvergensi media seperti media online, 
e-kertas, e-book, radio streaming, media sosial. Persaingan dalam bisnis media merupakan salah satufaktor pendorong media massa untuk menerapkan konsep ini karena perkembangan teknologitidak hanya mengandalkan format cetak (koran, majalah, buku) saja. MediaInovasi konvergensi diperlukan agar media massa mampu tetap bersaing dalamera bisnis saat ini. Sebagai salah satu bentuk inovasi, konvergensi media membutuhkan berbagaiproses dan tahapan dalam penerapannya. Penelitian Resmadi dan Yuliar menelusuri prosesdifusi inovasi konvergensi media dengan objek penelitian harian People'sPikiran, untuk menggambarkan bagaimana konvergensi media dapat diadopsi secara bertahap oleh sebuah media massa.

Beberapa ahli telah meramalkan kejatuhan media cetak. Seperti yang ditulis oleh Supadiyanto, Sejumlah tokoh dunia telah memprediksi munculnya teknologi koran paperless.Tokoh-tokoh tersebut adalah Roger F. Fidler, Bill Gates, Rupert Murdoch, dan Philip Meyer. Adaempat implikasi dari semakin meluasnya penggunaan koran tablet atau paperlessteknologi surat kabar dalam industri media massa di Indonesia. Pertama, implikasi langsungnya adalahtransfer teknologi besarbesaran dari media cetak ke basis bisnis surat kabar tanpa kertasyang sangat murah dalam hal pengadaan biaya produksi dan distribusidi seluruh dunia. Kedua, implikasi langsung lainnya adalah adanya perubahan dalamorientasi dan gaya hidup masyarakat dalam mengakses media massa sejak awal yangmasih konvensional, dengan membuka lembaran demi lembaran; beralih ke menekan tombol atau menekan tombollayar monitor. Ketiga, implikasi konten media akan lebih bervariasi; karena itumenjangkau daerah yang tidak disekat oleh batas negara/wilayah. Keempat, utama lainnyaimplikasinya adalah bahwa berbagai perusahaan media massa semakin mengintegrasikan multimediajaringan; sehingga terjadi konvergensi multimedia. Kelima, implikasi lain adalah bahwa perusahaan media cetak konvensional otomatis gulung tikar.

Media cetak Indonesia masih dalam tahap mengadopsi konvergensi media. Media cetak sedang berusaha memperbaiki konten dan belum memikirkan strategi pengembangan bisnis.Sisi positif dari teknologi digital adalah dapat membuka akses dan meningkatkan masyarakatpartisipasi dalam penyebarluasan informasi dan pengawasan penyelenggaraan pemerintahan yang demokratis. Manfaat yang diperoleh dari konversi dan konvergensi media tersebut adalah terjadinya efisiensi biaya produksi dan distribusi di samping jangkauan yang lebih luas tanpapembatasan regional apa pun.

Kemunculan internet memberikan peluang bagi non jurnalis (warga negara).wartawan) untuk mempublikasikan artikel mereka di media baru ini. Ini adalah perubahan besar sepanjang sejarahjurnalisme dimana saluran internet telah menggeser posisi jurnalis sejalan denganpenonton yang menjadi reporter. Ketika berbicara tentang kontribusi jurnalis wargasendiri, dapat dilihat dari berbagai peristiwa di belahan bumi yang informasinyadiseminasi sebenarnya berasal dari blog warga dalam hal ini bertindak sebagai jurnalis warga. setHettena, koresponden The Associated Press di San Diego yang menulis tentangmiliter merasakan peran penting dari konten blog pribadi dan konten web orangdemi liputannya.

Di Indonesia, jurnalisme warga bisa dibilang sudah mulai berkembang danKegunaannya sangat terasa ketika terjadi peristiwa besar seperti serangan teroris dan bencana alam.Sejak tahun 2002-an, media warga berkembang pesat berusaha mencari eksistensi di tengah-tengah suasana media tradisional. Dengan internet, media warga dapat menyebarluaskaninformasi berupa teks, audio, video, foto, komentar dan analisis. Bahkan mampumelakukan fungsi pers seperti pengawas, filter informasi, pengecekan fakta, dan bahkan mengedit.

Allan menekankan bahwa Citizen Media telah menjadi tren baru yang harus mendapatkan perhatian media tradisional, termasuk di Indonesia. Dia mengamati, dengan kekhawatirannya danketakutan, media tradisional (termasuk media cetak) mulai belajar bagaimana mengubah jurnalisme merekakonsep dari pendekatan otoriter ke pendekatan top-down untuk bersaing dalam hal iniera baru, termasuk salah satu strategi untuk tetap dekat dengan audiens mereka. Lalu bagaimana masa depanmedia warga? Tidak dapat disangkal bahwa jurnalisme warga akan menjadi konsep yang membuat frustrasimedia arus utama karena fungsi dan perkembangannya terus menarik perhatiandari warganya sendiri.

Untuk dapat tetap bertahan, media cetak harus mampu menjaga kredibilitas dan kepercayaannya informasi yang disajikan. Kredibilitas dan kepercayaan masyarakat ini hanya dapat dibangun dengan semangat profesionalisme jurnalis yang berpegang pada etika jurnalistik, yaitu untukmenyajikan informasi faktual yang diverifikasi dengan baik. Ini adalah tawaran kuat bagi media cetak untuk menjadimampu bertahan. 
Jarvis dalam Sugiya mengatakan bahwa industri media, khususnya media cetak, harusmelakukan perubahan jika tidak ingin terpinggirkan. Salah satunya adalah perubahan strategiharus dibuat agar media cetak dapat bertahan. Media cetak harus dapat mendefinisikan dirinya sendiri darimedia. Media cetak tidak bisa hanya kertas. Kekuatan dan nilai tidak hanya datang darikontrol konten dan distribusi. Strategi lain yang dilakukan media cetak adalah dengan mengintegrasikanisi surat kabar menjadi tablet elektronik.

Surat kabar (cetak) dan media online memiliki kelebihan dan kekurangannya masingmasing. Koran terkesan lambat, karena informasi yang telah dibombardir melalui televisi dan onlinemedia hanya dapat dinikmati oleh pembaca keesokan harinya. Adapun media online, mereka memilikikeuntungan menjadi cepat dan lengkap. Contoh: detik.com yang menyampaikan informasicepat dan up to date 24 jam terus menerus, serta media online yang memberikan tercepatberita tentang peringatan bencana alam dibandingkan dengan media cetak. Kelemahan media online, antara lain tentang keakuratan berita. Padahal media online cukup berkembangpesat dan media cetak diprediksi jatuh di negara-negara Barat, namun dalam konteksMedia cetak Indonesia masih bisa bertahan. Hal ini dibuktikan dengan adanya media cetak dimanaterdapat peningkatan jumlah media cetak baru pada tahun 2014 dibandingkan tahun sebelumnyatahun. Kecenderungan media cetak di Indonesia juga mampu beradaptasi dengan konvergensimedia cetak ke media online, tanpa meninggalkan keberadaan media cetak. Dengan demikian menjadi menarik untuk dikaji dan dikaji lebih dalam bagaimana media di Indonesia terkait dengan masa depanmedia cetak dalam menghadapi gempuran media online.

Jika Anda berbicara tentang solusi, Anda harus melihat dampak media online di media cetakmedia. Tentunya dengan keniscayaan era digital, jurnalis media cetak harus mampuuntuk melihat sisi positif media online bagi media cetak. Dampak positif media onlinepada media cetak adalah: Pertama, dapat menjadi mitra media cetak dalam menyampaikan pesan, dengan efisiensidan kecepatan waktu, dalam menembus dan menyampaikan berita yang diterbitkan oleh suatu media. Kedua,mengurangi penggunaan kertas yang boros, dalam hal ini menebang pohon khusus untuk kertas. Ketiga, simpanbiaya dan tidak memerlukan banyak gerakan, cukup klik maka berita telah dibaca.
Jurnalisme online dan jurnalisme konvensional (media cetak) memang jurnalismeyang memiliki perbedaan yang sangat mendasar, baik dari media yang digunakan, aktor atau pekerja di dalamnya, hinggakomposisi dan tampilan pesan yang juga berbeda, namun keduanya memiliki kelebihandan kekurangannya masing-masing. Keberadaannya tidak bisa dikatakan sebagai media yang menentang atau bersaingsatu sama lain, tetapi juga sebagai media yang dapat saling melengkapi dalam jurnalistik kegiatan atau dalam dunia jurnalistik. Kehadiran kedua jenis jurnalisme tersebut diintinya memiliki tujuan yang sama, yaitu berusaha memenuhi kebutuhan atau menyajikan informasi atau berita yang penting bagi publik atau khalayak luas. Namun, cara, sistem yang digunakan adalah berbeda, serta penyajiannya, menjadikan kedua jurnalisme tersebut dipandang sebagai jurnalisme ataujurnalisme media yang saling bersaing atau bersaing. Dalam jurnalisme konvensional,wartawan juga dituntut memiliki kemampuan/kepekaan terhadap situasi dan kondisiyang terjadi di lapangan. Perjuangan dan proses yang dilakukan dalam mencari, mengolah hinggamenyebarluaskan berita juga tidak semudah dan sesederhana yang terjadi dalam jurnalisme online.

Dampak positif dari perkembangan teknologi ini dapat menuntut jurnalis untuk menjadisemakin semangat dan mampu menguasai berbagai aplikasi untuk mendukung semakinkebutuhan informasi masyarakat yang bervariasi. Wartawan dituntut memiliki beberapa keterampilan lainselain hanya bisa menulis berita. Hal ini dapat dijadikan sebagai motivasi bagi para jurnalis untukterus berinovasi. Mungkin dampak positif lain dari media sosial adalah media sosial dapatjuga dapat digunakan sebagai tempat untuk mempromosikan berbagai produk jurnalistik dengan mudah dan murah. Semuanya tentu memiliki kelebihan dan kekurangan, salah satunya adalah media sosial.

\section{Kesimpulan}

Tantangan terbesar jurnalis di era informasi digital identik denganpersaingan antara media mainstream dan media baru dalam hal ini media online. ItuPihak yang merasakan dampak signifikan dengan hadirnya media online adalah jurnalisme yangtentunya sudah memiliki channel baru untuk menyebarkan informasi dan berita. media tradisionalyang pada saat kelahirannya tidak menggunakan saluran internet dalam praktek produksi berita sekarangmau tidak mau 
harus mengikuti arus media online jika tidak ingin ditinggalkan olehaudiens mereka.

Jurnalisme jenis baru yang muncul yaitu jurnalisme online yang diikutidengan perkembangan jurnalisme warga, telah membuat media arus utama khawatir tentangeksistensinya, meskipun tidak banyak media tradisional yang terbuka terhadap konsep-konsep baru.

Untuk dapat bertahan, media konvensional harus mampu menjaga kredibilitas dan kepercayaan terhadapinformasi yang disajikan. Kredibilitas dan kepercayaan masyarakat ini hanya dapat dibangun olehsemangat profesionalisme jurnalis yang menjunjung tinggi etika jurnalistik, yaitu untukmenyajikan informasi faktual yang diverifikasi dengan baik. Ini adalah tawaran kuat bagi media cetak untuk menjadimampu bertahan. Industri media, khususnya media cetak, harus melakukan perubahan jika tidak ingin dipinggirkan. Salah satunya adalah perubahan strategi yang harus dilakukan agar media cetakmedia dapat bertahan. Media cetak harus dapat mendefinisikan dirinya dari media tersebut. Media cetaktidak bisa hanya kertas. Kekuatan dan nilai tidak hanya datang dari kontrol konten dandistribusi. Strategi lain yang dilakukan media cetak adalah dengan mengintegrasikan isi surat kabarmenjadi tablet elektronik.

\section{Daftar Pustaka}

Amar, M. D. (1984). Hukum Komunikasi Jurnalistik. Bandung: Alumni

Aw, S. (2010). Komunikasi Sosial Budaya. Cet Pertama. Yogyakarta: Graha Ilmu

Departemen Pendidikan Nasional. (2003). Kamus Besar Bahasa Indonesia. cet ke III. Jakarta: Balai Pustaka

Effendy, O. U. (1984). Dimensi-Dimensi Komunikasi. Bandung: Alumni

Kurniawan, J. (1991). Ensiklopedi Pers Indonesia. Jakarta: Gramedia Pustaka Utama

Kurniawan, M. (2006). Jurnalisme Warga: Prospek dan Tantangannya. Sosial Humoniora. Vol. 11. No. 2.

Kusuma, S. (2016). Posisi Media Cetak Di Tengah Perkembangan Media Online Di Indonesia. Jurnal Prodi IImu Komunikasi. Unika Atma Jaya. Vol.5. No.1.

McQuail, D. (2017). Teori Komunikasi Massa. Edisi Kedua. Jakarta: Penerbit Airlangga

Mondry. (2008). Pemahaman Teori dan Praktik Jurnalistik. Cet. Pertama. Bogor Selatan: Ghalia Indonesia
Nurkinan. (2017). Dampak Media Online Terhadap Perkembangan Media Konvensional. Jurnal Politikom Indonesiana. Vol. 2 No. 2

Palapah. M.O, dan Syamsuddin, A. (1975). Studi IImu Publisistik. Bandung : Fakultas Publisistik UNPAD

Resmadi, I., dan Yuliar, S. (2014). Kajian Difusi Inovasi Konvergensi Media di Harian Pikiran Rakyat. Jurnal Sosioteknologi. Vol. 13 No. 2

Suharyanto. A., Hidyat. T. W. (2018). Revealing Medan's Chinese Ethnic Identity in Advertising Grief at Harian Analisa Newspaper. Budapest International Research and Critics Institute (BIRCIJournal). 1 (4); 83-92.

Wahyudin. (2016). Pengantar Jurnalistik Olahraga. Makassar: Fakultas Ilmu Keolahragaan Universitas Negeri Makassar 